\title{
分子ディスプレイ法による革新的有機溶媒内酵素反応の開拓
}

\author{
植田充美
}

\section{Development of Revolutionary Enzymatic Reactions in Organic Solvents with Molecular Display}

\author{
Mitsuyoshi UEDA \\ Division of Applied Life Sciences, Graduate School of Agriculture, Kyoto University, \\ Kitashirakawa-oiwake-cho, Sakyo-ku, Kyoto 606-8502, Japan
}

(Received July 17, 2010)

\begin{abstract}
We have seen increasing use of the term "White biotechnology". White biotechnology involves the use of microbial cells and enzymes in the production of bulk and fine chemicals such as amino acids and polymers. This generally results in cleaner processes with minimum waste generation and energy use. Most of the organic syntheses using enzymes are carried out in nearly anhydrous organic solvents or solvent-free media. Ionic liquids have more recently emerged as another nonaqueous media, which, in view of their low vapor pressure, are viewed as "green solvents". Organic solvents may alter the structure and activity of enzymes that usually function in an aqueous environment. One alternative is to immobilize the enzymes on solid supports to increase their function and stability in response to organic solvents or increased temperatures. Enzymes may be stabilized by chemical and physical processes. With chemical methods, enzymes are immobilized by strong covalent bonding, but changes in protein structure often result. In physical stabilization processes, the interactions between enzymes and solids usually are weaker, resulting in fewer changes in the enzyme's structure. Yeast cell surface engineering is an alternative approach that immobilizes enzymes on the yeast cell surface. Proteins are immobilized by using an outer shell cell-wall protein, the C-terminal half of alpha-agglutinin. Display of enzymes on the yeast cell surface has at least two advantages relative to other physical immobilization methods. First, the displayed enzymes can be readily produced in a standard fermentation. No further work is required to either purify or immobilize the enzymes. Second, enzyme displayed on the yeast cell surface can be modified directly by conventional genetic engineering, which enables error-prone PCR, DNA shuffling, and combinatorial mutagenesis to be used quickly and efficiently to create strains (whole-cell biocatalysts) with enhanced enzyme activity.
\end{abstract}

Key words — molecular display; cell surface engineering; white biotechnology; whole-cell biocatalysts; genetic immobilization; organic solvent

\section{1.はじめに}

酵素反応は温和な条件で，主に水溶液中で行わ れ，その反応選択性と特異性が魅力である。しか し，化学工業に使われる触媒と比較して，有機溶媒 中では酵素タンパク質の失活により，せっかくの機 能が発揮できない，この弱点を克服するために，酵 素の各種固定化や遺伝子組換えなどの操作が加えら れ，いくつかの酵素が有機溶媒内で使われるように なってきた。しかし，どれも万能とは言えず，ホワ

京都大学大学院農学研究科応用生命科学専攻（T6068502 京都市左京区北白川追分町)

e-mail: miueda@kais.kyoto-u.ac.jp

本総説は, 日本薬学会第 130 年会シンポジウム S55 で

発表したものを中心に記述したものである.
イトバイオテクノロジーの発展が必須の現在におい て，革新的な発想と技術が求められている。われわ れは，こういう状況下で，これまで開拓してきた細 胞表層工学 (Cell Surface Engineering) を発展させ, 細胞と酵素が一体化した生体触媒（Whole-cell biocatalysts）を開発した。これは，酵素に従来の固定 化に匹敵する安定化とタンパク質の弱点である増殖 性と保存性という物性を賦与する結果となつた。さ らに，反応ライブラリーを生み出す酵素変異体ライ ブラリーの調製を簡便に高速に実現した. このよう な分子ディスプレイを活用した有機溶媒内酵素反応 の開拓は，薬学の精緻な合成反応を，酵素の本来的 に持つ高機能性を基盤とするホワイトバイオテクノ ロジーに変換していく上で，環境負荷を低減し，地 
球環境に優しい化学反応の普及に大いに貢献してい くものと考えており，化学産業に使われている合成 反応への展開を企図した生体触媒を取り上げ紹介す る.

\section{2. 分子ディスプレイによる新しい生体触媒の作} 製

目的の遺伝子をタンパク質に変換していくタンパ ク質調製系として，従来の細胞内発現系や分泌系に 対して，分子ディスプレイ系では，タンパク質が細 胞の表層や細胞膜などの上に安定な形で提示（分子 ディスプレイ）され，細胞を 1 つの支持体として， 分子ディスプレイされたタンパク質をいつも生きた まま，必要ならいつでも増幅できるなど，その生体 触媒としての活性や機能解析が容易となる。さら に，タンパク質のアミノ酸配列分析をしなくても, PCR（遺伝子増幅）法などの併用により，導入さ れた DNA の配列から分子ディスプレイされたタン パク質のアミノ酸配列が決定できるという他の方法 論の追随を許さない，次世代シークエンシング時代 に適応した変異体も高速に創出される。こういつた ゲノム情報分子をタンパク質機能分子に変換する新 しく，簡易で，迅速で，しかも，多くの組み合わせ の（コンビナトリアル）分子ライブラリーから適合 するものをシステマティックに選択することのでき る手法として展開してきたのが，ニューバイオテク ノロジーとしての「コンビナトリアル・バイオエン ジニアリング」手法である. ${ }^{1,2)}$

われわれは，酵母の細胞表層への分子ディスプレ イ法一酵母の細胞表層工学一という新しいバイオテ クノロジー分野を開拓してきた（Fig. 1). ${ }^{1-6)} 1999$ 年ノーベル医学生理学賞を受賞した Blobel 教授の 「タンパク質におけるシグナル説」で周知のごとく, 細胞内のすべてのタンパク質は，個々に固有の「ア ドレス」を指定する情報を持ち，その情報に基づい て輸送され局在化し，そこで機能を発揮している. 酵母を用いた分子ディスプレイでは，細胞表層で機 能を発揮しているタンパク質の「アドレス」を指定 する遺伝子情報を用いた機能タンパク質の新しい発 現手法として，【細胞表層工学（Cell Surface Engineering)】を考案した。最も単純でヒトの生活に 既に密接に係わっている真核細胞であるパン酵母 Saccharomyces cerevisiae を用いた場合，この細胞 表層最外殼に位置する $\alpha$-アグルチニンの分子情報
を活用することによって種々の酵素やタンパク質を 細胞表層にディスプレイすることが可能となってき た～$\alpha$-アグルチニンの分子構造は，分泌シグナル • 機能ドメイン・細胞壁ドメイン（セリンとスレオニ ンに富む C 末 320 アミノ酸残基）からなっており, この C 末 320 アミノ酸残基の C 未端にグリコシル ホスファチジルイノシトール（GPI）アンカー付着 シグナルが存在する。 したがって，この分泌シグナ ルと機能ドメインを操作することによって，これま でに，異種由来の酵素や各種因子や受容体など分子 サイズの大きいタンパク質を，単独で，あるいは， 協奏的に細胞表層に発現提示させることに成功し， 酵母がこれまで持たなかつた機能を持った新機能酵 母を創製してきた。このような細胞は，アメリカの Chemical \& Engineering News [Vol. 75, p. 32 (1997) ] でもいち早く取り上げられ，「アーミング酵母 (Arming Yeast)」と命名されており，こういった 技術は「アーミング技術」として，タンパク質と細 胞を一体化できる Whole-cell biocatalyst を創製で きる革新的基盤技術となってきている.

\section{3. 有機溶媒内での Whole-cell biocatalyst の反応}

加水分解反応を触媒する酵素を有機溶媒下で用い ることにより，その反応の可逆性を利用した，いわ ゆる逆反応により物質合成を行う例が多い。ここで は，リパーゼ，エステラーゼやプロテアーゼなどの 分子ディスプレイによる Whole-cell biocatalyst を

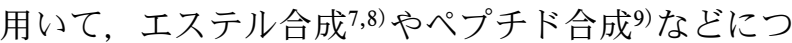
いての最近の注目されている実例を紹介する.

バイオマスの利用の 1 つとして, 植物由来プラス チックである生分解性プラスチックのポリ乳酸は注 目を集めている．現在の汎用性プラスチックは石油 を原料にして化学合成によって作られており，微生 物による分解を受けないため，使用後は焼却や埋め 立て処分される，そのため，焼却処理では二酸化炭 素が放出され，また，埋め立て処分では環境中に蓄

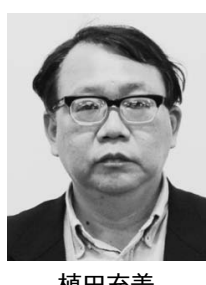

植田充美
京都大学大学院農学研究科応用生命科 学専攻生体高分子化学分野教授. 1979 年京都大学工学部工業化学科卒業（福 井三郎教授)。学振奨励研究員 (京大医 学部 沼正作教授)。京都大学工学部助 手, 助教授.バイオエナジ一顧問. 三 菱化学生命科学研客員. 2003 年より現 職. 2010 年バイオインダストリー協会 賞受賞. 


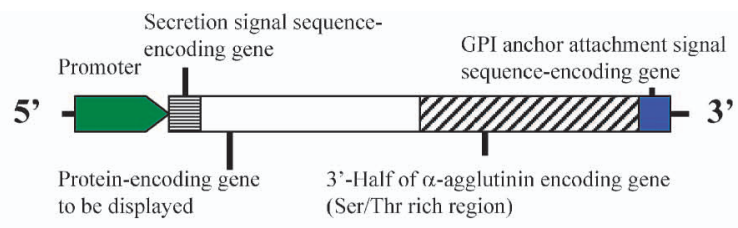

Molecular design of the fusion gene for cell-surface display

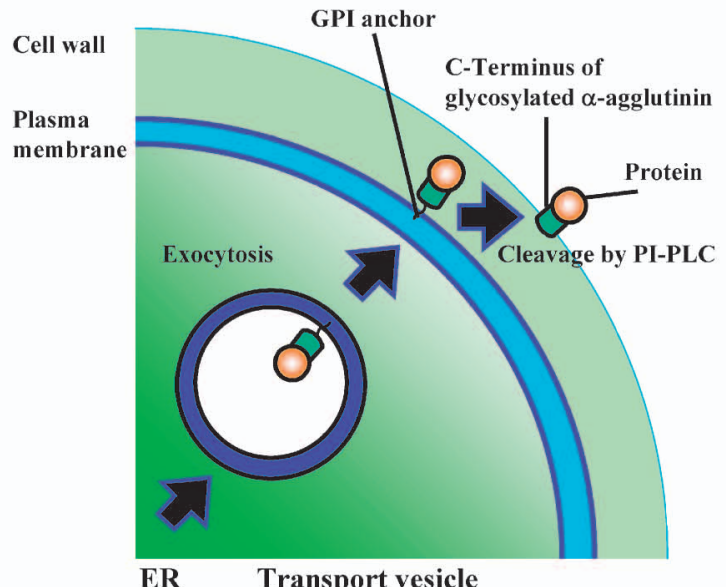

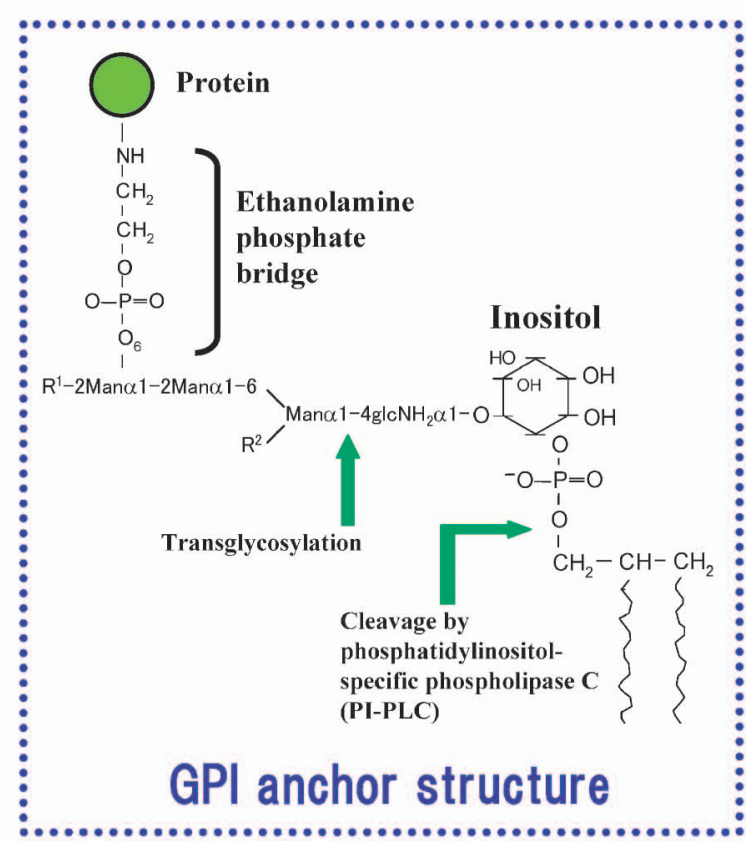

Transportation mechanism of the foreign protein to the cell wall

Fig. 1. Mechanism of Cell Surface Engineering (Molecular Display)

積していく。したがって，このような環境負荷の大 きい素材をバイオマスから製造し，使用後は微生物 によって分解されて最終的には再び植物に戻るとい うカーボンニュートラルが実現可能な素材に置換し ていくことは急務である。しかし，生分解性プラス チックは汎用性プラスチックと比較して，物性の面 で劣るということや高価格であるということが障害 となり，普及が遅れているのが現状である，物性の 問題は近年盛んに研究がなされており，価格化につ いても，ポリ乳酸のポリマー化の多段階からなるス テップを減らす研究が行われている。 しかし，直接 のポリマー化を行う際には乳酸が十分に精製されて いないと成形したプラスチックに色がついてしまう という問題がある．現在のポリ乳酸の工業的な製造 工程では，乳酸の精製は水酸化カルシウムと酸を用 いて行われているため, 最終的に副産物として大量 の塩が生成することが問題視されている，そこで,

Whole-cell biocatalyst を用いて, 乳酸の精製を, 安 価に，そして環境負荷の少ない形で行うことができ る手法が開拓された。

その手法とは，先に述べたように，乳酸の精製過 程で問題となっている副産物の問題を解決するため
に，乳酸をエステル化することにより乳酸の分離を 容易にし，それに続く加水分解反応を行うことによ つて純度の高い乳酸を得るという方法で，乳酸を工 ステル化する過程である。乳酸をエステル化するた めに，乳酸とアルコールの脱水反応を用いることに し，その脱水反応を触媒する酵素としてリパーゼを 選択した。リパーゼの本来の反応はエステル結合の 加水分解反応であるが，その逆反応であるエステル 合成反応やエステル交換反応にも作用することが知 られている，そこで，実際に使用する酵素として， 担子菌類酵母 Candida antarctica が生産するリパー ゼ B（CALB）を選択し，酵母分子ディスプレイシ ステムを用いて CALB を細胞表層にディスプレイ することによるCALB 提示酵母の構築を試みた. このシステムを用いて酵素を酵母の細胞表層にディ スプレイすると，酵母 1 細胞あたりおよそ $10^{4}-10^{5}$ 分子の酵素が最密充填的にディスプレイされた Whole-cell biocatalyst が創製できる（Fig. 2)。さら に，酵素が酵母細胞の細胞壁に固定化されることに より，酵素の熱安定性が増す。このことは，物質合 成に酵素を用いる上で重要である。また，CALB は水溶系及び有機溶媒系の両方において高い活性や 


\section{Living yeasts}

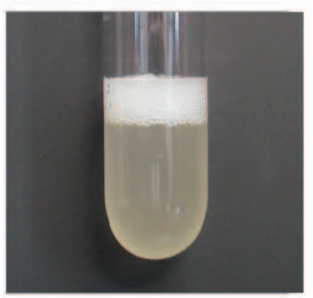

\section{Lyophilized yeasts}

\section{Lyophilization}

(Whole-cell biocatalyst)

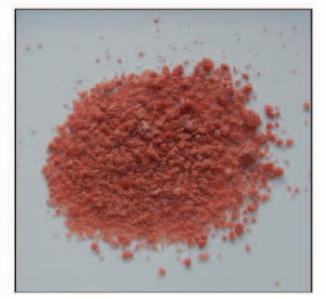

Fig. 2. Preparation of Whole-cell Biocatalysts with Displayed Enzymes

安定性を保つため，物質合成への応用が期待されて いる. CALB の触媒反応に関する現在までの報告 では，その大半が Novozym 435 (Novo-Nordisk) などの固定化リパーゼを使用している．固定化酵素 は安定性が非常に高いため利用価値が大きいという 特徵を有する反面，特別な化学修飾により製造され ているためにコストが高いという問題がある。そこ で，ここに示したような酵母分子ディスプレイシス テムを用いて CALB 提示酵母を構築すれば，酵母 を培養するだけで固定化された状態のCALB を得 ることができ，コストの問題を解消することができ ると考えられる.

実際にCALB をディスプレイするために，前述 に従って，遺伝子を融合させ，表層最外殼に固定化 した。目的とするエステル反応は CALB 本来の反 応である加水分解反応の逆反応なので，反応系には できるだけ水分が少ないほうがよいと推測できる.

CALB 提示酵母を有機溶媒中での乳酸エステル合 成に用いるため, CALB 提示酵母菌体を培養・洗 浄後，凍結乾燥することにより水分を除き，粉状の 乾燥菌体を調製した．凍結乾燥することによって細 胞表層にディスプレイした CALB の活性が失われ ていないことは，凍結乾燥前後での CALB 提示酵 母の $p$-Nitrophenyl butyrate に対する加水分解活性 を測定することにより確認した。活性を保持してい ることが確認された乾燥菌体 $50 \mathrm{mg}$ を用いて，50 $\mathrm{ml}$ スクリューキャップ付試験管の中に溶媒として $5 \mathrm{ml}$ の水飽和へプタン, 基質として $500 \mathrm{mM}$ のエタ ノールと $10 \mathrm{mM}$ の乳酸を添加し， $30^{\circ} \mathrm{C}$ で振とうす ることによって乳酸エチルの合成反応を行った。そ の反応液を HPLCで分析した結果，乳酸エチルの 生成を確認することに成功した。 反応系に Molecu- lar sieves を加えて脱水した無水へプタン, 反応系 に $10 \%$ の水を加えた水を含むへプタン，水飽和へ プタンの 3 種類の溶媒を用いて合成反応を行ったと ころ，溶媒として水飽和へプタンを用いた反応系で 最も効率よく乳酸エチルが生成することが確認され た。つまり, 酵素が活性を示し, かつ加水分解の逆 反応を触媒するには，水飽和のようなごく少量の水 分が必要であるということになる.

乳酸エチルの合成における酵素反応の様子を調べ るために反応のタイムコースをとると，200 時間以 降は反応が停止していると思われた，反応はエ夕 ノール過剰の条件下で行っていたので，反応系にも う一方の基質である乳酸をさらに加えてみたとこ ろ，合成の再開がみられた。また，合成反応再開時 の酵素反応の初速度は反応初期と比較して遜色はな かった。このことから，反応停止の原因は酵素の失 活ではなく, 加水分解反応と合成反応とが平衡に達 したからではないかと考えられる。また，合成反応 の再開がみられたことから，有機溶媒にCALB 提 示酵母をさらしていても酵素活性は失われないとい うことが分かる.さらに, 効率よく乳酸エチル合成 を行う条件を検討するために，温度を上げて反応を 行った。 その結果，温度の上昇とともに酵素反応の 初速度が増加し，反応時間 111 時間での合成効率は $50^{\circ} \mathrm{C}$ で $74 \%$ にまで上昇させることに成功した。

また，CALB は D-乳酸も基質として認識できる かを 120 時間の合成反応で調べたところ，L-乳酸よ りやや高い合成効率を得られることが分かった.

CALB を用いて乳酸の光学分割をすることはでき ないが，乳酸発酵を行う際に L 体のみ，又は，D 体のみを生産する微生物を使用すれば，どちらの乳 酸の精製にもCALB を提示した酵母を使用するこ 
とが可能である. ${ }^{8)}$

次に, 生理活性ペプチドの合成の例として, $\beta$ アラニンと L-ヒスチジンがペプチド結合したカル ノシンの例を簡単に紹介する，カルノシンは，脳内 に存在する生理活性ペプチドとして最近，注目を集 めてきており，抗疲労や抗酸化効果により，サプリ メントとしても広がりつつある.このペプチドは, 非天然の $\beta$-アラニンを含むため，ノンリボソーム 合成が必要であり，われわれは，カルノシン合成酵 素の存在が未知であるため, 分解酵素カルノシナー ゼの遺伝子をクローニングし，前述の方法により， 酵母細胞表層に提示して，有機溶媒下で，分解反応 の逆反応で，この生理活性ペプチドの合成を試み た。 その結果，有機溶媒でも疎水的な有機溶媒下で 合成が進むことを見い出し（Fig. 3)，試験管内合 成に初めて成功した。ささら，イオン液体の適用を 試みたところ，疎水的性質を持つイオン液体内で同 様の反応が実現できた. ${ }^{9}$

以上のように，細胞表層工学により創製された Whole-cell biocatalyst は非常に簡便で安価な新しい 生体触媒の創製手法となり，水系はもちろん，有機 溶媒やイオン液体系での合成反応にもその適用範囲 を広げていっている.

\section{4. 生体触媒の有機溶媒耐性一新しい合成生物学} による触媒開発 10,11$)$

細胞表層工学では, 酵素の担体となる酵母の有機 溶媒耐性も重要であるが，真核微生物についての有 機溶媒耐性の研究はほとんどない。われわれは，有 機溶媒存在下でのドライイーストの連続培養中に, イソオクタンに耐性を示す酵母 S. cerevisiae KK-211 株を世界で初めて単離した。 KK-211 株は野生株で は生育できないイソオクタン（logPow $=4.8 ）$ 含有 培地においても生育可能であり，そのほかにもノナ ンやオクタン, ジフェニルエーテルといった有機溶 媒にも耐性を示す。KK-211 株の細胞膜脂質中の飽 和脂肪酸含量を調べたところ，その割合の増加が確 認されたが，さらに野生株と KK-211 株ではイソオ クタンドロップに対する親和性が大きく異なり,

KK-211 株ではほとんご吸着しないことからも，細 胞表層の組成の変化がうかがえる。そこで, KK-211 株の有機溶媒耐性機構を明らかにするとと もに，有機溶媒耐性株の分子育種を試みた。

KK-211 株の有機溶媒耐性機構を明らかにするた め, DNA マイクロアレイ解析により KK-211 株と 野生株とで網羅的に転写レベルを比較し，有機溶媒 に係わっていると考えられる遺伝子を絞り込んだ. その結果，KK-211 株では多くの遺伝子の転写レベ

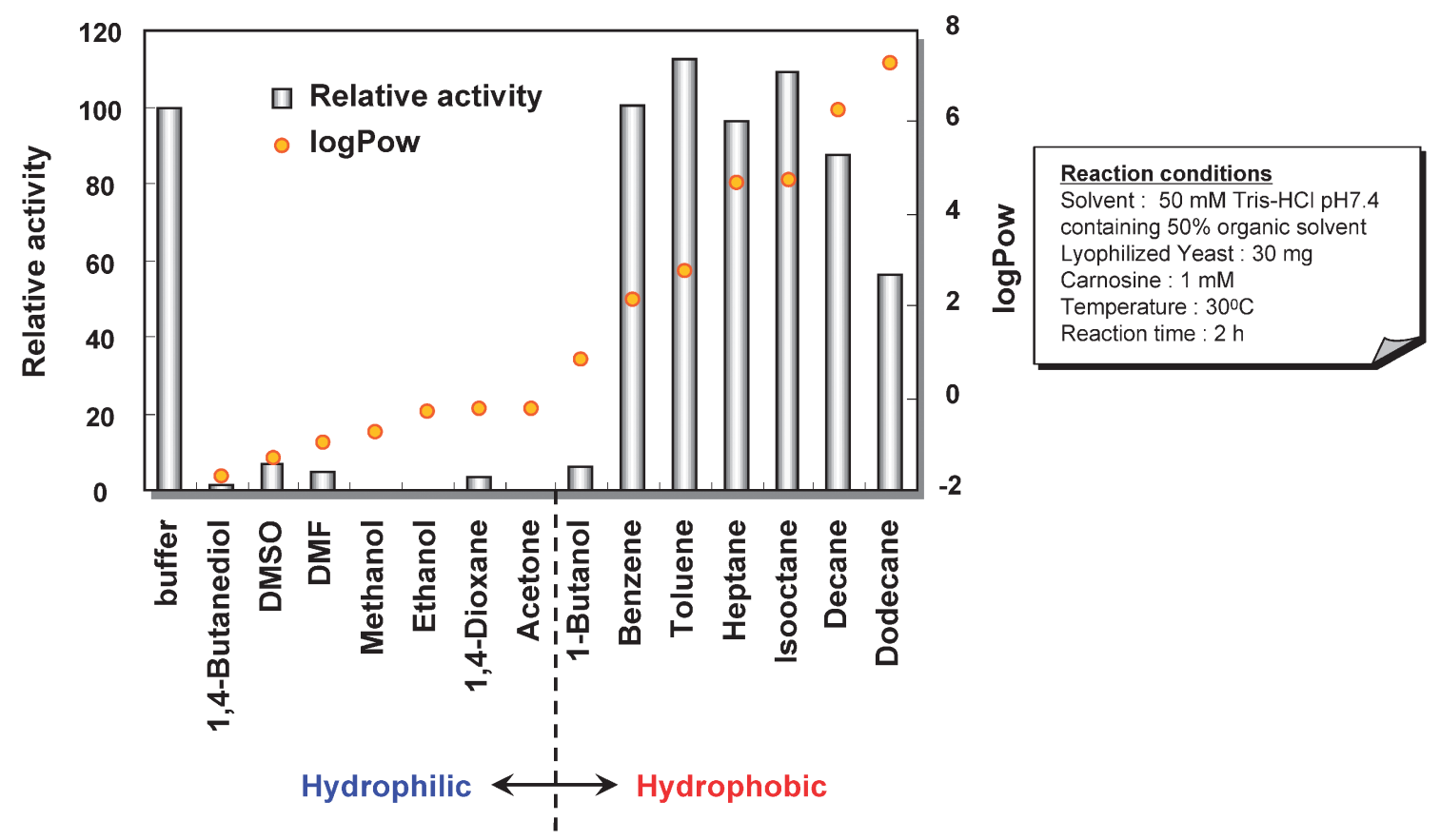

Fig. 3. Effect of Organic Solvents on Displayed Carnosinase as the Whole-cell Biocatalyst 
ルの上昇が確認された。これらの遺伝子群の中には, $\mathrm{ABC}$ トランスポーターなど細胞表層タンパク質を コードするものが多く含まれていた。さらに，これ らの遺伝子の発現制御機構を調べると, 共通してプ ロモーター領域中に PDRE (Pleiotropic Drug Response Element）が存在していたことから，PDRE を持つ遺伝子の発現制御を行っている転写因子 Pdr1p に着目した。そこで，KK-211 株の遺伝子転 写プロファイルを分析したところ，興味深いことに pdr1 変異株の遺伝子転写プロファイルと高い類似 性を示した。したがって，有機溶媒耐性をもたらす 要因として PDR1 遺伝子の介在が考えられたため,

KK-211 株の PDR1 遺伝子配列を調べてみると，野 生株と比べて 4 カ所のアミノ酸変異の存在を発見し た.

実際に，有機溶媒耐性がこの変異に起因するかを 確かめるため，野生株ゲノム中の PDR1 遺伝子に 変異導入を試みた。 KK-211 株の pdr1の 4 力所の 変異のうち，821 番目のアミノ酸がアルギニンから セリンに置換している変異（R821S）に着目した。 この変異（PDR1-R821S）を相同組換えによって実 験室株 MT8-1 のゲノム DNA に導入し，有機溶媒 耐性の有無を調べたところ，PDR1-R821S 変異を 導入した MT8-1 変異株ではイソオクタンやノナン
などの有機溶媒含有培地においても良好な生育を示 した．この結果から，KK-211 株の有機溶媒耐性が PDR1-R821S 変異に起因していることが明らかに なり，この変異をゲノム中に導入することによつ て，野生株の有機溶媒耐性化を再現することもでき た。さらに，PDR1-R821S 変異の導入により有機 溶媒耐性化した MT8-1 株を用いて，水/有機溶媒二 相系にて 3-オキソブタン酸ブチルの還元反応を試 みたところ，PDR1-R821S 変異を導入した株は反 応開始 30 時間後にほぼすべての基質を還元してお り，有機溶媒耐性を持つだけでなく実際の物質変換 等に必要な触媒活性も保持していることが明らかと なった（Fig. 4).

\section{5. 今後の展望}

本稿では，酵母分子ディスプレイシステムによ り，これまでにない新しい革新的な Whole-cell biocatalyst を創製し，より環境への負荷が少ない反 応系の構築の展開について紹介した。また，有機溶 媒耐性酵母の解析により，耐性をもたらす因子を同 定するとともに，転写因子 PDR1 を改変すること によって，本来有機溶媒耐性を持たない酵母などの 真核微生物の生体触媒への応用展開に関して，容易 に有機溶媒耐性の付与が，合成生物学的に，可能で あることを明らかにした。有機溶媒耐性という複雑
Substrate

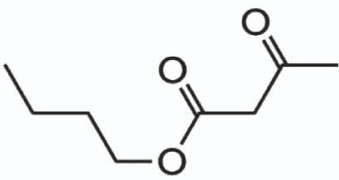

Butyl 3-oxobutanoate
Product

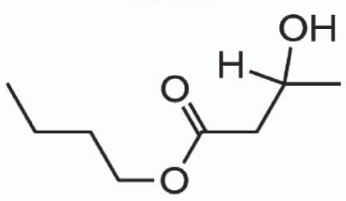

Butyl 3-hydroxybutanoate

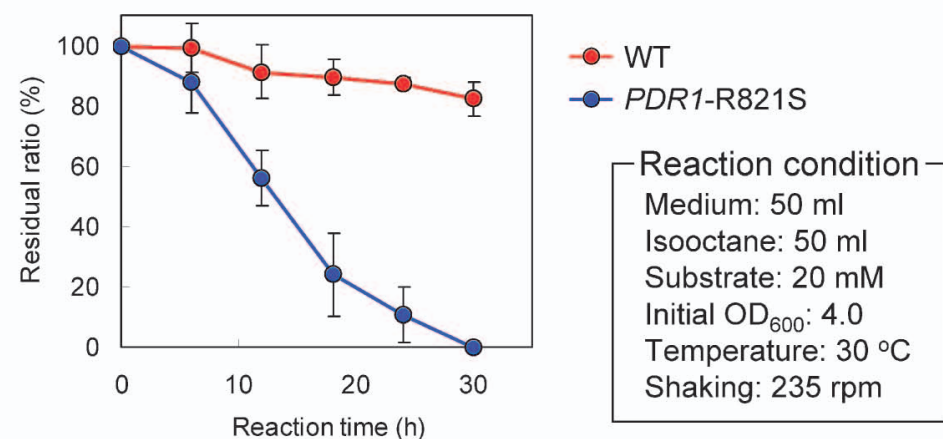

Fig. 4. Microbial Reduction with the Reconstructed Organic-solvent-tolerant Yeast 
な要因のからむ表現型を，関連する転写制御因子の 変異により再現し, 有機溶媒内で機能する新しい生 体触媒の開発を可能にした。得られた技術は，今 後，環境負荷の大きい疎水性化合物の合成など有機 溶媒を用いる生体触媒反応において大きく貢献でき るであろうと考えられる。

\section{REFERENCES}

1) Ueda M., Kondo A., "Kagaku Frontier," Vol. 9, Kagaku-Dojin Publishing Company, INC, Kyoto, 2003.

2) Ueda M., "Frontier of Combinatorial Bioengineering," CMC Publishing Co., Ltd., Tokyo, 2004.

3) Ueda M., Bioscience and Industry, 55, 275278 (1997).

4) Ueda M., Kagaku to Seibutsu, 35, 525-532 (1997).
5) Ueda M., Bionics, 27, 31-35 (2007).

6) Ueda M., Yakugaku Zasshi, 129, 1277-1284 (2009).

7) Shiraga S., Kawakami M., Ishiguro M., Ueda M., Appl. Environ. Microbiol., 71, 4335-4338 (2005).

8) Inaba C., Maekawa K., Morisaka H., Kuroda K., Ueda M., Appl. Microbiol. Biotechnol., 83, 859-864 (2009).

9) Inaba C., Higuchi S., Morisaka H., Kuroda K., Ueda M., Appl. Microbiol. Biotechnol., 86, 1895-1902 (2010).

10) Matsui K., Hirayama T., Kuroda K., Shirahige K., Ashikari T., Ueda M., Appl. Microbiol. Biotechnol., 71, 75-79 (2006).

11) Matsui K., Teranishi S., Kamon S., Kuroda K., Ueda M., Appl. Environ. Microbiol., 74, 4222-4225 (2008). 